\title{
Preliminary limnological survey of Ori stream, Iwo, Osun State, Nigeria
}

\author{
Emmanuel Olusegun AKINDELE ${ }^{1,2^{*}}$, Temitayo Abisoye ADEDAPO ${ }^{1}$, \\ Olawumi Omotola OLAWOYE ${ }^{1}$, Godwin Oladele OLUTONA ${ }^{3}$ and \\ Babasola Williams $\mathrm{ADU}^{4}$
}

\author{
${ }^{I}$ Department of Biological Sciences, Bowen University, P.M.B. 284, Iwo, Osun State, Nigeria. \\ ${ }^{2}$ Department of Zoology, Obafemi Awolowo University, P.M.B. 13, Ile-Ife, Osun State, Nigeria. \\ ${ }^{3}$ Department of Chemistry and Industrial Chemistry, Bowen University, P.M.B. 284, Iwo, Osun State, Nigeria. \\ ${ }^{4}$ Department of Biological Sciences, Ondo State University of Science and Technology, Okiti Pupa, Nigeria. \\ *Corresponding author, E-mail: eoakindele@yahoo.com; Tel +234-8036574615
}

\begin{abstract}
Ori stream (one of the tributaries of River Oba, Iwo, Osun State, Nigeria) was studied from October to December 2013 with the aim of providing baseline information on its water quality, phytoplankton primary productivity and invertebrate faunal composition. Plankton samples were collected by towing plankton net over a 2 metres horizontal distance, while benthic macroinvertebrate samples were collected by kick-sampling technique. Hydrological and some physico-chemical variables were determined in-situ, and water samples collected for further physico-chemical analyses in the laboratory. A total of 17 phytoplankton species, seven species of zooplankton and eight species of benthic macroinvertebrates were recorded. The upper reach of the stream was the most polluted with the presence of biological indicators of poor water quality, while the lower reach recorded some biological indicators of good water quality. Although the upper reach recorded the highest gross primary productivity, the highest net primary productivity was recorded at the stream's lower reach. Water quality typically decreased from the upper reach of the stream towards the middle reach but later picked up at the lower reach before discharging into River Oba. The physico-chemical and biotic nature of the different reaches were a reflection of human activities in and around the stream.
\end{abstract}

(c) 2015 International Formulae Group. All rights reserved.

Keywords: Benthic macroinvertebrates, conservation, headwater stream, plankton; primary productivity, water quality.

\section{INTRODUCTION}

Freshwater ecosystems have been subjected to significant impacts for centuries, in some cases millennia, and are continuing to be influenced by ever-growing human needs (Higgins and Duigan, 2009). As a result, they have lost a greater proportion of their species and habitats than ecosystems on land or in the oceans, and they face increasing impacts from pollution, over-harvesting, habitat destruction, invasive species and climate change (World Resources Institute et al., 2000; Millennium Ecosystem Assessment, 2005). Freshwaters are most vulnerable to pollution due to their easy accessibility for disposal of pollutants and wastewaters (Bhat and Pandit, 2014). The evaluation of water quality in most countries 
has become a critical issue in recent years, especially due to concerns that freshwater will be a scarce resource in the future (Alberto et al., 2001; Simeonov et al., 2003; Singh et al., 2004; Quadir, 2008). It is against this background that protecting the integrity of world freshwaters is given topmost priority in the $21^{\text {st }}$ century (USEPA, 2007; Chinhanga, 2010; Bhat et al., 2014). In an ideal situation, the quality of freshwaters should be assessed by the use of physical, chemical and biological parameters in order to provide a complete spectrum of information for appropriate water management. Among these three surrogate parameters, the biological assessment of water quality is now largely developing because of the inclusion of biological indicators in water quality guidelines and in the assessment of environmental impacts (IliopoulouGeorgudaki et al., 2003; Singh et al., 2013).

There are three main streams which drain through the ancient town of Iwo, namely: Aiba stream, Ori stream and Yaunyanun stream. These streams are all tributaries of River Oba which is of historic importance to the town, and ultimately discharges into River Osun. While Aiba stream has been copiously studied for its physico-chemical and biological water quality (Akindele, 2013; Atobatele and Olutona, 2013; Akindele and Liadi, 2014; Akindele and Olutona, 2014), the other two streams have not been previously accounted for, in terms of their physico-chemical and biotic nature. The current study on Ori stream was carried out against this background, and in view of the fact that the management of large freshwater systems (e.g. Rivers Oba and Osun) is intimately linked to the management of their watershed and floodplain (Hambler and Canney, 2013). In Nigeria for instance, smaller water bodies (e.g. streams and brooks) are often ignored in limnological studies, while attention is often focused on larger freshwater systems (e.g. lakes, reservoirs and rivers). This neglect has undermined the ecological importance of such headwaters in the overall conservation of the nation's inland waters. This paper is premised on the fact that the sustainability of large freshwater systems could be forecast if the health status of their tributaries is well documented. Thus, this study aimed at providing a baseline information on the health status of Ori stream in relation to its physico-chemical condition, phytoplankton composition and primary productivity, and, invertebrate faunal composition.

\section{MATERIALS AND METHODS}

\section{The study area}

Ori stream is one of the three major streams that drain through the ancient town of Iwo, Osun State. Unlike the other two streams, it is in the outskirts of the town but various developmental projects have spread to the area, as a result of increasing human population. Owing to rising human needs, the stream is subjected to varying degrees of environmental stress as it flows through the town and ultimately discharges into River Oba.

\section{Sampling and field in-situ determinations}

The study lasted over a period of three months from October to December 2013, and sampling was conducted on monthly basis between the hours of 9 am and $12 \mathrm{pm}$. Five stations were established along the longitudinal axis of the stream (Figure 1). Site descriptions and anthropogenic activities at each sampling site are provided in Table 1. Water temperature, $\mathrm{pH}$ and electrical conductivity were determined in-situ using a mercury-in-glass thermometer, $\mathrm{pH}$ meter and conductivity meter respectively. Also determined in-situ were flow velocity by float displacement method; channel width with a calibrated tape; water depth and Secchi depth with a calibrated Secchi disc; and discharge estimated from the product of flow velocity, channel width and water depth (Chapman and Kimstach, 2006). Dissolved oxygen (DO) and 
biological oxygen demand $\left(\mathrm{BOD}_{5}\right)$ samples were collected in $300 \mathrm{ml}$ amber bottles. DO samples were immediately fixed with Winkler's reagents to halt all biological activities, while the $\mathrm{BOD}_{5}$ samples were taken to the laboratory and incubated at room temperature over a period of five days. Primary productivity samples were also collected on each sampling day and for each sampling station in a set of three bottles designated as: initial bottle (IB), white bottle (WB) and dark bottle (DB).

Water samples for physico-chemical analyses were collected in new and uncontaminated plastic containers thoroughly cleansed with distilled water and later rinsed with water samples to be collected. Plankton samples were collected by towing a plankton net (64 $\mu \mathrm{m}$ mesh size) over a 2 meter horizontal distance and concentrating it in a $100 \mathrm{ml}$ specimen bottle. Plankton samples were also preserved in-situ in 5\% formalin to ensure the integrity of the samples. Benthic macroinvertebrate samples were collected by using a hand-held pond net to collect the organisms after dislodging them by KickSampling Technique (Freshwater Biological Association, 2011), and preserved in $70 \%$ alcohol. Sediment samples were collected in polythene bags for textural analysis in the laboratory.

\section{Laboratory analyses}

Dissolved oxygen samples were analysed in the laboratory using the Winkler's titration method. $\mathrm{BOD}_{5}$ samples were also fixed with Winkler's reagents on the fifth day and analysed the same way as DO samples. Primary productivity samples were also analysed by using oxygen method (Molnar, 2005), experimentally over a period of six hours. The initial bottle (IB) was fixed at the start of the experiment with Winkler's reagents, while the transparent white bottle (WB) was exposed to direct sunlight and immersed in the same water from its natural environment. The dark bottle (DB) was an opaque bottle and kept in a dark cupboard while the experiment lasted. After six hours, both WB and DB were also fixed with Winkler's reagents and the three bottles analysed for their dissolved oxygen content using the iodotitrimetric method. Phytoplankton primary productivity of the samples was estimated using the following mathematical illustrations:

Net Productivity $=$ WB-IB

Respiration $=$ IB-DB

Gross productivity $=$ Net productivity + Respiration $=($ WB-IB $)+($ IB-DB $)=$ WB-DB (Molnar, 2005)

Since the experiment lasted for only 6 hours and primary productivity is usually expressed per time, the values were multiplied by a factor of 4 so that the productivity values are now expressed per day.

Total solids (TS), total suspended solids (TSS) and total dissolved solids (TDS) were determined by gravimetric method. $\mathrm{Ca}^{2+}$, $\mathrm{Mg}^{2+}, \mathrm{Na}^{+}, \mathrm{K}^{+}, \mathrm{NO}_{3}{ }^{-}$and $\mathrm{PO}_{4}{ }^{3-}$ were determined by atomic absorption spectrophotometry. Percentage composition of sand, silt and clay and the textural class of each sediment sample were determined by using the Pipette method (Kettler et al., 2001).

Phytoplankton and zooplankton samples were further concentrated and reduced to $10 \mathrm{ml}$ volume for viewing under a Max II 1202.4000 model compound light microscope. Identification was carried out by taking note of their morphological features and by using relevant plankton identification guides (Fernando, 2002). Identification of benthic macroinvertebrates was also aided with relevant guides (Freshwater Biological Association, 2011; Umar et al., 2013).

\section{Statistical analyses}

The various data obtained were analysed using descriptive statistics and oneway analysis of variance (ANOVA). The community structures of the organisms were determined using Shannon-Weiner diversity index, Margalef diversity index, Simpson's 
diversity index, and species (Pielou's) evenness index.

\section{RESULTS}

\section{Physico-chemical parameters}

The spatial variations of physicochemical water parameters are presented in Figures 2-4. The general trend for flow velocity and discharge was that of decrease from the stream's upper reach to its lower reach, although only flow velocity was statistically significant $(\mathrm{p}<0.05)$. Channel width, water depth and Secchi depth however recorded their highest values at a mid-reach station (St. 2). TS, TDS and TSS typically decreased $(p<0.05)$ from the upper reach Station 1, downstream to the lower reach Station 5. The lowest $\mathrm{pH}$ was recorded at the upper reach (St. 1) and the highest at St. 5 with no significant spatial variation $(\mathrm{p}>0.05)$. Electrical conductivity showed significant $(\mathrm{p}<0.05)$ spatial variation and recorded its highest and lowest values at St. 1 St. 5 respectively. The lowest and highest values of $\mathrm{Na}$ and $\mathrm{K}$ were recorded at Stations 3 and 1, and, Stations 2 and 3 respectively. $\mathrm{NO}_{3}{ }^{-}$ recorded its lowest value at $\mathrm{St} .5$ and highest at St. 1, while $\mathrm{PO}_{4}{ }^{3-}$ recorded its lowest and highest values at Stations 5 and 3 respectively. $\mathrm{DO}$ and $\mathrm{BOD}_{5}$ recorded their highest values at Station 1, and the lowest at Station 3.

\section{Phytoplankton composition, community structure and primary productivity}

Five divisions of phytoplankton were recorded in this study, namely: blue-green bacteria, bryophyta, ciliophora, chlorophyta and diatomea (bacillariophyta) (Table 2). These altogether comprised a total of 17 species, with chlorophyta alone comprising 11 species. Blue-green bacteria comprised three species, while the other three divisions were mono-specific. A total of 2,596 individuals were recorded and Hormidium rivalare was the most abundant, while Drepanocladus aduncus was the least abundant. The community structure of phytoplankton is presented in Table 3. The lowest number of species richness was recorded at Station 3, while the highest was at Station 1. Abundance of phytoplankton was lowest at Station 2 and highest at Station 1. Neither species richness nor abundance of phytoplankton showed significant spatial variation $(p>0.05)$ in the stream. The three diversity indices recorded their lowest values at Station 3. ShannonWeiner and Margalef diversity indices were both highest at Station 1, while Simpson diversity index was highest at Station 5. Evenness of species was lowest at Station 3 and highest at Station 4. The gross primary productivity, respiration and net primary productivity values in the sampled stations of Ori stream are shown in Figure 5. Gross primary productivity was highest at St. 1 followed by St. 5, while the lowest value was at St. 2. Respiration was also highest at St. 1, followed by St. 2 while Stations 3 and 5 recorded the lowest value. Net primary productivity was highest at Station 5, followed by Station 1 while the least value was at Station 2. Only net primary productivity and respiration however showed significant difference $(p<0.05)$ in their spatial variation.

\section{Invertebrate faunal composition, distribution and community structure}

A total of 15 invertebrate species were recorded in the stream, comprising seven species of zooplankton and eight species of benthic macroinvertebrates (Table 2). Zooplankton comprised four broad taxonomic groups, namely: Protozoa, Rotifera, Cladocera and Insecta (Merozooplankton). Protozoans were the most dominant both qualitatively and quantitatively, followed by rotifers. Crustacea and Insecta were both monospecific in distribution, and Insecta was the least abundant of the main taxonomic groups recorded. Arcella sp. occurred in all the stations and was the most abundant zooplankton species. Station 5 recorded the highest species richness and abundance of zooplankton, while the least values were both 
recorded at Station 3. There was no significant difference $(p>0.05)$ in the spatial variation of zooplankton species richness and abundance. The three diversity indices followed the same trend as species richness and abundance, with the lowest values at St. 3 and the highest at St. 5. Conversely, evenness of species was lowest at St. 5 and highest at St. 4 (Table 3).

Four main taxonomic groups were also recorded for the benthic macroinvertebrates, viz: Annelida, Crustacea, Insecta and Mollusca. Insecta comprised five species, while the other three groups were monospecific. Lanistes ovum occurred in four out of the five sampled stations, Lumbricidae and Potomonautes sp. occurred at two stations each, while other species occurred at only one station each. Chironomus sp. which occurred only at Station 1 was the most abundant macroinvertebrate sp., followed by Lanistes ovum and then, Gerris sp. No significant spatial variation $(\mathrm{p}>0.05)$ was also recorded in terms of species richness and abundance of the stream's benthic macroinvertebrates. Stations 2 and 3 were both monospecific in terms of macroinvertebrate distribution, and there were no diversity indices recorded. The three diversity indices as well as evenness of species were however higher in Station 5 than in Station 1.

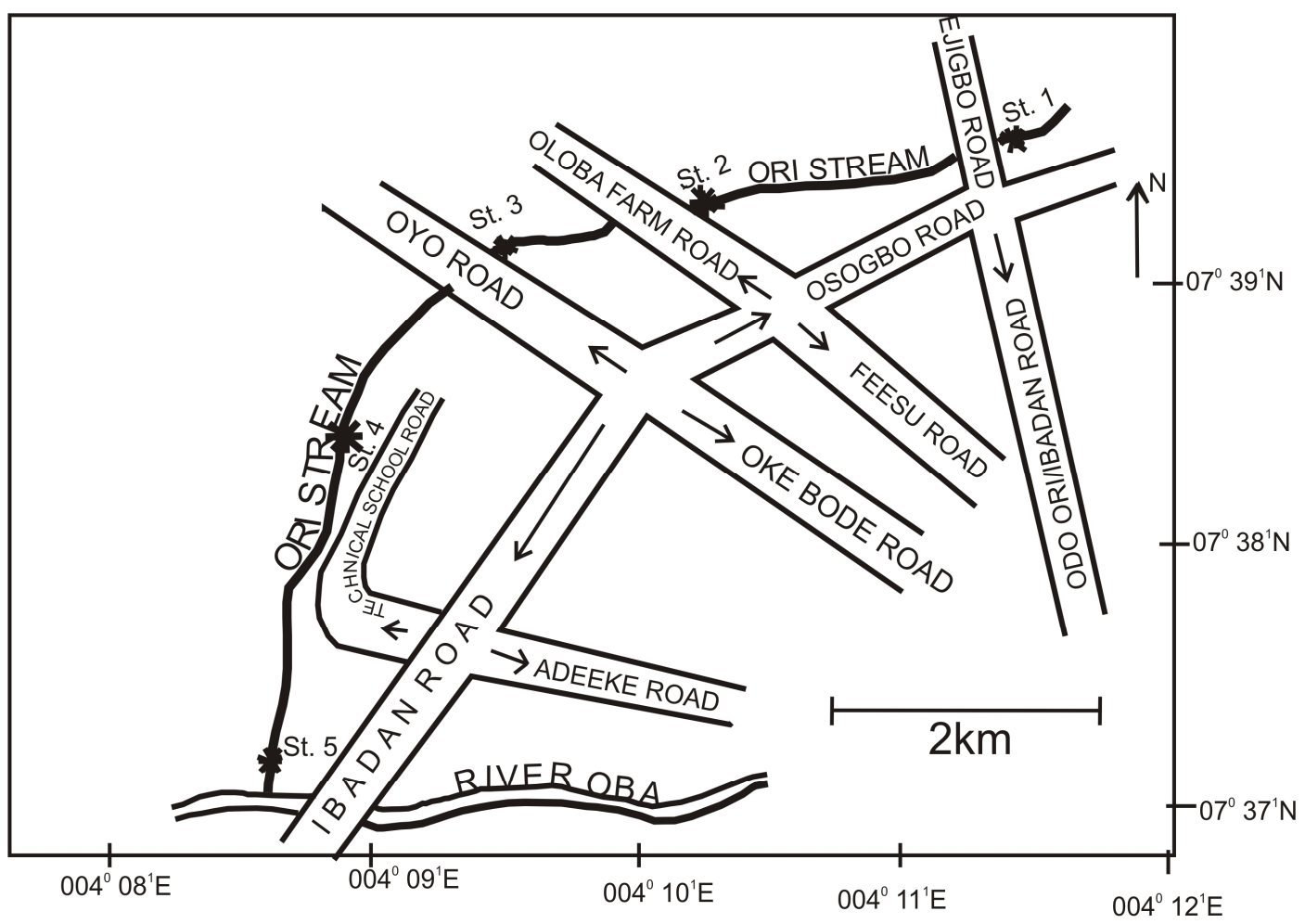

Figure 1: Ori stream showing the sampling stations and its drainage through the ancient town of Iwo, Osun State, Nigeria. 


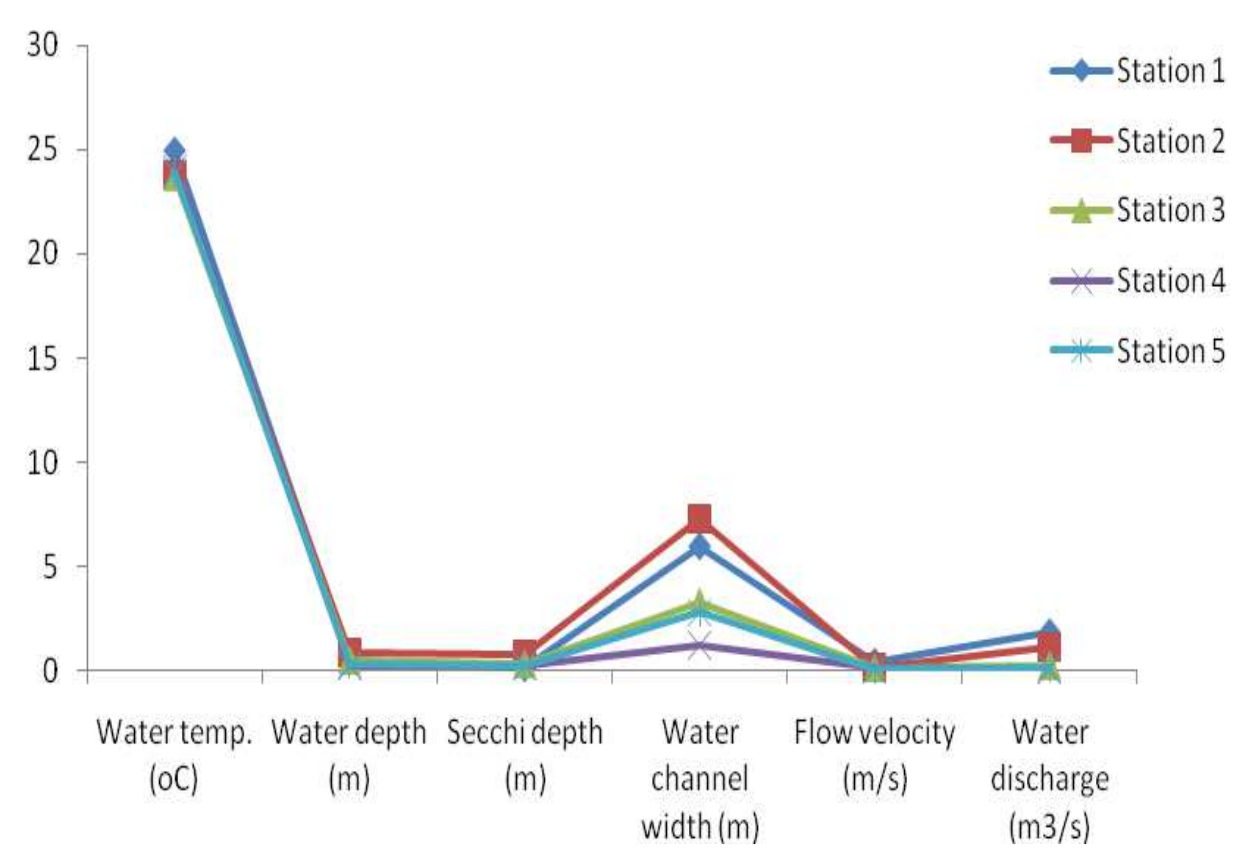

Figure 2: Physical and hydrological variables of Ori stream, Iwo, Osun State, Nigeria (OctoberDecember, 2013).

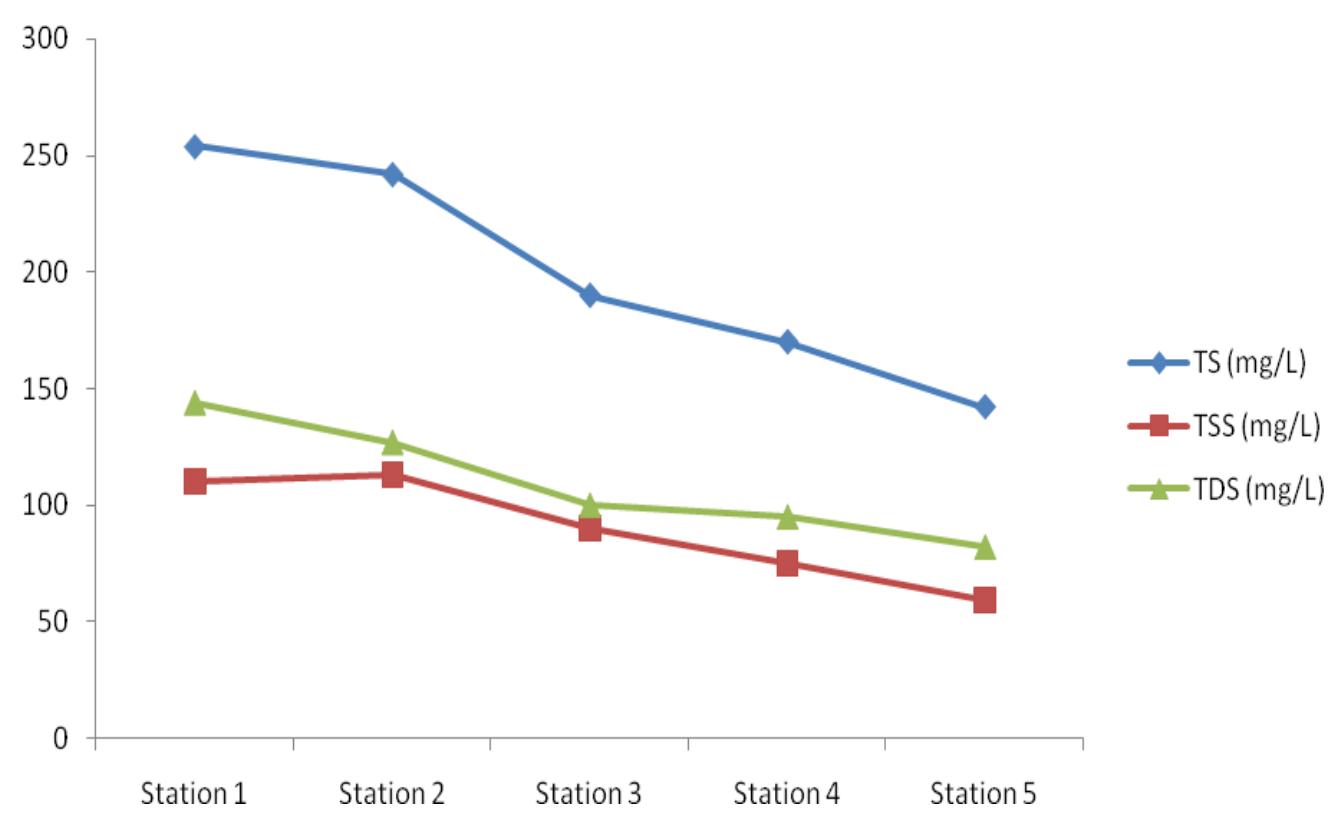

Figure 3: Concentrations of solids in Ori stream, Iwo, Osun State, Nigeria (October-December, 2013). NB: TS- total solids; TSS- total suspended solids; TDS- total dissolved solids. 


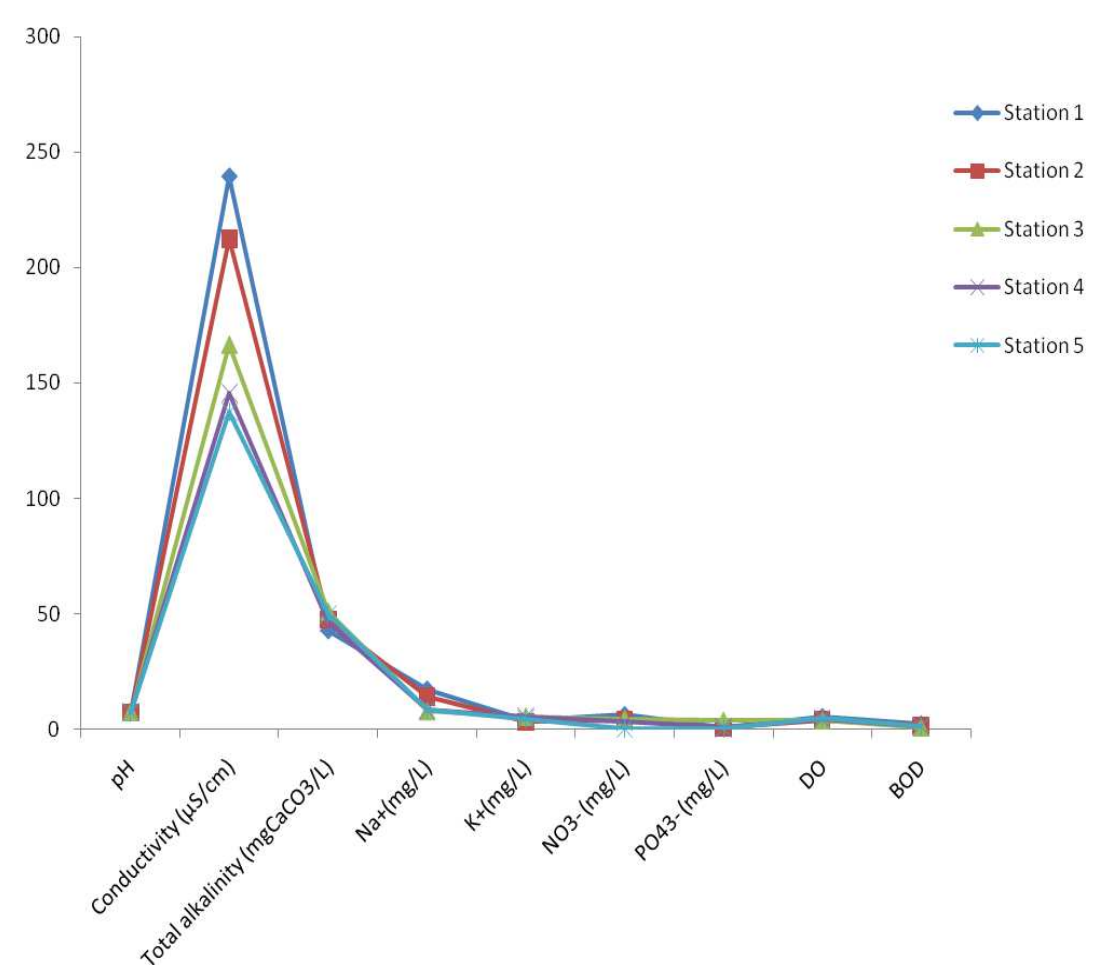

Figure 4: Chemical and nutrient parameters of Ori Stream, Iwo, Osun State, Nigeria (OctoberDecember, 2013). NB: DO- Dissolved oxygen; BOD- Biological oxygen demand.

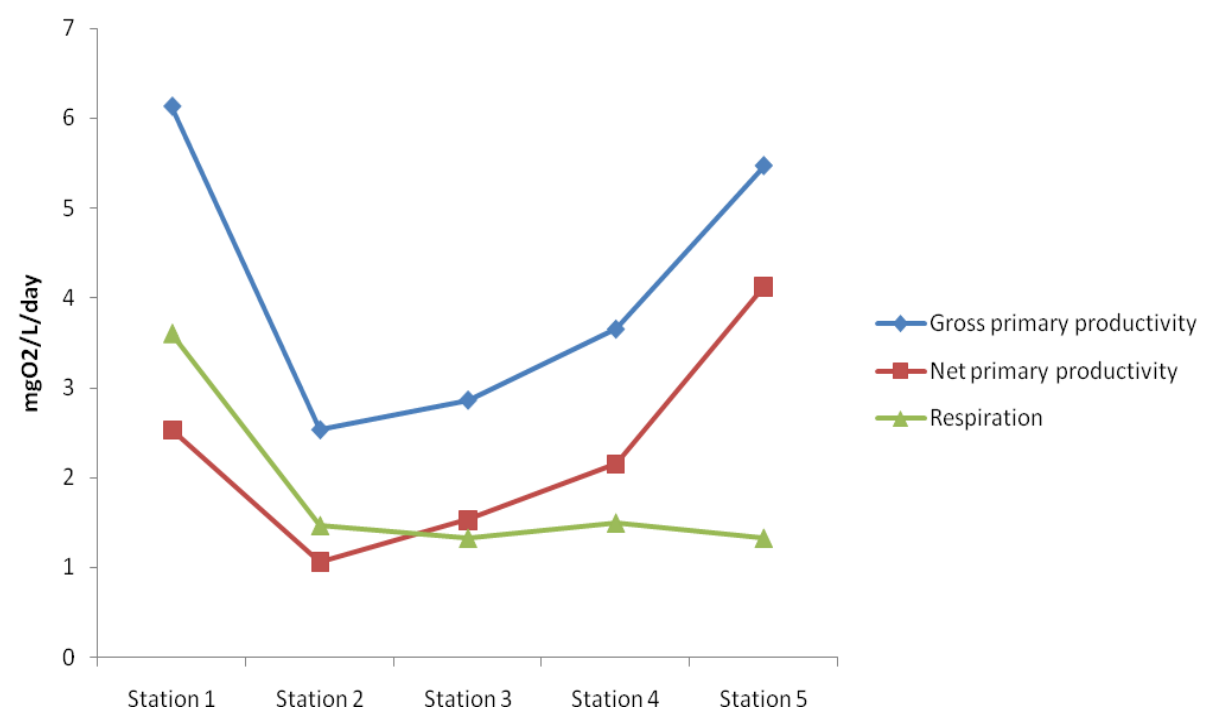

Figure 5: Phytoplankton primary productivity (mean \pm s.d.) in Ori stream, Iwo, Osun State, Nigeria (October-December, 2013). 
Table 1: Site descriptions of the sampling stations in Ori stream, Iwo, Osun State, Nigeria.

\begin{tabular}{lll}
\hline Station & Location & Description \\
\hline 1 & Upper reach & $\begin{array}{l}\text { Along Ejigbo/Ogbomoso road; abattoir situated closely; human } \\
\text { activities around include farming and dumping of human and animal } \\
\text { wastes; about 10\% vegetation cover. }\end{array}$ \\
\hline 2 & Upper reach & $\begin{array}{l}\text { Along Oloba road, about 2 km downstream of Station 1; high level of } \\
\text { organic matter deposition and decomposition; about 15\% vegetation } \\
\text { cover. }\end{array}$ \\
\hline 3 & Middle reach & $\begin{array}{l}\text { Along Oyo road, about 1.5 km downstream of Station 2; high } \\
\text { vegetation cover (about 90\%) with lots of detritus. }\end{array}$ \\
\hline 4 & Middle reach & $\begin{array}{l}\text { Along Technical School road, about } 2 \mathrm{~km} \text { downstream of Station 3; } \\
\text { about 45\% vegetation cover. }\end{array}$ \\
\hline 5 & Lower reach & $\begin{array}{l}\text { Adjacent to Ibadan road, roughly 2 km downstream of Station 4 and } \\
\text { 200 meters upstream of River Oba; about 65\% vegetation cover; cash } \\
\text { crops (e.g. Cocoa and Plantain) characterized the surrounding } \\
\text { terrestrial surface. }\end{array}$ \\
\hline
\end{tabular}

Table 2: Occurrence and distribution of plankton and benthic macroinvertebrates in Ori stream, Iwo, Osun State, Nigeria (October-December, 2013).

\begin{tabular}{|c|c|c|c|c|c|c|}
\hline \multirow{2}{*}{$\begin{array}{l}\text { Taxon } \\
\text { PHYTOPLANKTON }\end{array}$} & \multicolumn{5}{|c|}{ Sampling Station/Abundance } & \multirow{2}{*}{$\begin{array}{c}\text { Total } \\
\text { Abundance }\end{array}$} \\
\hline & 1 & 2 & 3 & 4 & 5 & \\
\hline \multicolumn{7}{|l|}{ Blue green bacteria } \\
\hline Microcystis marginata & 44 & 0 & 0 & 0 & 44 & 88 \\
\hline Oscillatoria limosa & 88 & 0 & 0 & 0 & 22 & 110 \\
\hline O. putrid & 0 & 66 & 0 & 88 & 66 & 220 \\
\hline \multicolumn{7}{|l|}{ Bryophyta } \\
\hline Drepanocladus aduncus & 0 & 0 & 22 & 0 & 44 & 66 \\
\hline \multicolumn{7}{|l|}{ Ciliophora } \\
\hline Hemiophrys procera & 154 & 44 & 0 & 44 & 22 & 264 \\
\hline \multicolumn{7}{|l|}{ Chlorophyta } \\
\hline Closterium aciculare & 110 & 22 & 0 & 0 & 0 & 132 \\
\hline C. moniliferum & 22 & 0 & 0 & 0 & 0 & 22 \\
\hline Hormidium rivalare & 0 & 0 & 198 & 88 & 88 & 374 \\
\hline Microspora amoena & 22 & 0 & 44 & 66 & 88 & 220 \\
\hline Mougeotia genuflexa & 22 & 66 & 0 & 0 & 0 & 88 \\
\hline Rhizoclonium hieroglyphicum & 0 & 0 & 22 & 44 & 22 & 88 \\
\hline Scenedesmus dimorphus & 0 & 44 & 0 & 0 & 66 & 110 \\
\hline Spirogyra quinine & 154 & 0 & 0 & 0 & 0 & 154 \\
\hline Stigeoclonium flagelliferum & 0 & 22 & 154 & 88 & 44 & 308 \\
\hline Ulothrix tenerrima & 110 & 0 & 0 & 0 & 0 & 110 \\
\hline U. zonata & 66 & 44 & 0 & 0 & 0 & 110 \\
\hline \multicolumn{7}{|l|}{ Diatomea (Bacillariophyta) } \\
\hline Asterionella gracillima & 44 & 44 & 0 & 44 & 0 & 132 \\
\hline $\begin{array}{l}\text { Total phytoplankton } \\
\text { abundance }\end{array}$ & 836 & 352 & 440 & 462 & 506 & 2,596 \\
\hline
\end{tabular}




\begin{tabular}{|c|c|c|c|c|c|c|}
\hline \multicolumn{7}{|l|}{ ZOOPLANKTON } \\
\hline \multicolumn{7}{|l|}{ Protozoa } \\
\hline Amoeba radiata & 22 & 0 & 0 & 0 & 0 & 22 \\
\hline Arcella sp. & 66 & 22 & 22 & 44 & 132 & 286 \\
\hline Gromia fluviatilis & 44 & 0 & 0 & 0 & 22 & 66 \\
\hline \multicolumn{7}{|l|}{ Rotifera } \\
\hline Asplanchna brightwelli & 0 & 0 & 0 & 44 & 88 & 132 \\
\hline Trichocerca similis grandis & 0 & 44 & 0 & 0 & 22 & 66 \\
\hline \multicolumn{7}{|l|}{ Crustacea } \\
\hline Nauplius larva & 0 & 22 & 44 & 22 & 22 & 110 \\
\hline \multicolumn{7}{|l|}{ Insecta } \\
\hline Unidentified insect larva & 0 & 0 & 0 & 0 & 22 & 22 \\
\hline Total zooplankton abundance & 132 & 88 & 66 & 110 & 308 & 704 \\
\hline \multicolumn{7}{|l|}{ MACROINVERTEBRATES } \\
\hline Lumbricidae & 1 & 0 & 0 & 0 & 1 & 2 \\
\hline \multicolumn{7}{|l|}{ Crustacea } \\
\hline Potomonautes sp. & 0 & 0 & 0 & 1 & 1 & 2 \\
\hline Chironomus sp. & 29 & 0 & 0 & 0 & 0 & 29 \\
\hline Geris sp. & 0 & 0 & 0 & 0 & 3 & 3 \\
\hline Libellula sp. & 0 & 0 & 0 & 0 & 1 & 1 \\
\hline Nepa sp. & 0 & 0 & 0 & 0 & 1 & 1 \\
\hline Chrysomelidae & 0 & 0 & 0 & 0 & 1 & 1 \\
\hline \multicolumn{7}{|l|}{ Mollusca } \\
\hline Lanistes ovum & 0 & 3 & 1 & 4 & 1 & 9 \\
\hline $\begin{array}{l}\text { Total macroinvertebrate } \\
\text { abundance }\end{array}$ & 30 & 3 & 1 & 5 & 9 & 48 \\
\hline
\end{tabular}

Table 3: Community structure of plankton and benthic macroinvertebrates in Ori stream, Iwo, Osun State, Nigeria (October-December, 2013).

\begin{tabular}{lccccccc}
\hline Biotic groups & $\begin{array}{c}\text { Sampling } \\
\text { station }\end{array}$ & $\begin{array}{c}\text { Species } \\
\text { richness }\end{array}$ & Abundance & H' & 1-D & d & $\begin{array}{c}\text { Species } \\
\text { evenness }\end{array}$ \\
\hline Phytoplankton & 1 & 11 & 836 & 2.19 & 0.87 & 1.49 & 0.81 \\
& 2 & 8 & 352 & 2.01 & 0.86 & 1.19 & 0.94 \\
& 3 & 5 & 440 & 1.26 & 0.66 & 0.66 & 0.70 \\
& 4 & 7 & 462 & 1.90 & 0.84 & 0.98 & 0.95 \\
& 5 & 10 & 506 & 2.19 & 0.87 & 1.45 & 0.89 \\
& Overall & $\mathbf{1 7}$ & $\mathbf{2 5 9 6}$ & $\mathbf{2 . 6 7}$ & $\mathbf{0 . 9 2}$ & $\mathbf{2 . 0 4}$ & $\mathbf{0 . 8 5}$ \\
\hline Zooplankton & 1 & 3 & 132 & 1.01 & 0.61 & 0.41 & 0.92 \\
& 2 & 3 & 88 & 1.04 & 0.63 & $0 . .45$ & 0.94 \\
& 3 & 2 & 66 & 0.64 & 0.44 & 0.24 & 0.94 \\
& 4 & 3 & 110 & 1.06 & 0.64 & 0.43 & 0.96 \\
& 5 & 6 & 308 & 1.48 & 0.71 & 0.87 & 0.73 \\
Benthic & $\mathbf{3}$ & $\mathbf{7}$ & $\mathbf{7 0 4}$ & $\mathbf{1 . 6 3}$ & $\mathbf{0 . 7 6}$ & $\mathbf{0 . 9 2}$ & $\mathbf{0 . 7 3}$ \\
\hline
\end{tabular}




\begin{tabular}{lccccccc}
\hline macroinvertebrates & 2 & 1 & 3 & 0 & 0 & 0 & 1 \\
& 3 & 1 & 1 & 0 & 0 & 0 & 1 \\
& 4 & 2 & 5 & 0.50 & 0.32 & 0.62 & 0.82 \\
& 5 & 7 & 9 & 1.83 & 0.81 & 2.73 & 0.89 \\
& Overall & $\mathbf{8}$ & $\mathbf{4 8}$ & $\mathbf{1 . 3 0}$ & $\mathbf{0 . 5 9}$ & $\mathbf{1 . 8 1}$ & $\mathbf{0 . 4 6}$ \\
\hline
\end{tabular}

H': Shannon-Weiner diversity index; 1-D: Simpson's diversity index; d: Margalef diversity index

\section{DISCUSSION}

Although dissolved oxygen was highest at the upper reach (St. 1) in spite of its pollution status, it was not necessarily an indication of the site's health status, but of waters upstream of the site since it is a lotic system. Furthermore, the upper reach station has a relatively high flow velocity which has been established to have a direct relationship with dissolved oxygen saturation (Voshell, 2002). Besides the upper reach station, the concentrations of dissolved oxygen $(<5.0$ $\mathrm{mg} / \mathrm{L}$ ) in the other four stations were below the recommendation for aquatic life (Chapman and Kimstach, 2006). The spatial trend in the conductivity values as well as the concentrations of ions and nutrients suggests that the upper reach (St. 1) was the most polluted, and the stream recovered from pollution stress as it flowed down along its course. Discharge (water volume) was highest at the upper reach and drastically reduced before the stream discharged into River Oba. Recently (i.e. 2013), the upper reach of the stream was dredged due to the impending danger of the stream overflowing its banks in the rainy season, but this was not extended to the middle and lower reaches of the stream, hence a reduced discharge in the latter area. This may however further worsen the water quality in the middle reach, as a result of low water volume (discharge) to dilute the upstream pollution. The importance of discharge in ameliorating pollution was underscored by Carr and Neary (2006) when they stated that discharge influences the susceptibility of a stream to pollution. Streams with low discharge have a reduced capacity to dilute pollution and degrade wastes.
Phytoplankton far out numbered zooplankton and benthic macroinvertebrates, in species richness and abundance. This finding goes a long way to underscore the importance of phytoplankton in the energy flow of a freshwater system. The upper reach (St. 1) and the lower reach (St. 5) were relatively high in phytoplankton species richness and abundance as well as gross primary productivity. Although the upper reach station recorded the highest gross primary productivity, the highest net primary productivity was recorded at the lower reach station. This could easily be attributed to very high rate of oxygen consumption taking place at the upper reach station, in which respiration alone consumed $58.7 \%$ of the gross primary productivity. The implication of this could be reduced chemical energy available for higher trophic level organisms (e.g. zooplankton and macroinvertebrates), and this was most likely the reason for low zooplankton and macroinvertebrate production at the station. Based on the primary productivity values, the lower reach Station 5 may be regarded as the most productive since it had the highest net primary productivity value.

There was a poor representation of both zooplankton and benthic macroinvertebrates in Ori stream. Only seven species of zooplankton were recorded and Rotifera was not the most dominant group as against several studies on the zooplankton fauna of Nigerian freshwaters (Akin-Oriola, 2003; Ayodele and Adeniyi, 2006; Akindele and Adeniyi, 2013). This poor species composition, rarity of rotifers as well as the absence of cladocerans in the stream could be indicative of its poor biological water quality. The benthic macroinvertebrate faunal 
composition of the stream which was characterised by eight taxa seemed to be the most reliable tool for assessing its biological water quality. The only two taxa (Chironomus sp. and Lumbricidae) recorded at the upper reach station are biological indicators of poor water quality (Friedrich et al., 2006), one of which (i.e Chironomus sp.) accounted for about $63 \%$ of the total number of macroinvertebrates. Based on the distribution of macroinvertebrates, the lower reach station seemed relatively healthiest of all with the presence of biological indicators of good water quality such as the Libellulidae and Potomonautidae (Friedrich et al., 2006), though they occurred rarely. The highest taxa richness of benthic macroinvertebrates at the lower reach station may also be attributed to its streamside (riparian) forest with about $90 \%$ vegetation cover. Literatures indicate that streamside forests support the distribution of macroinvertebrate fauna by keeping stream's thermal structure within a tolerance range, and, making food available for them directly through input of particulate food (leaf litter, soils, wood, etc.), and indirectly by affecting the structure and productivity of microbial (algae, bacteria) food web (Hussain and Pandit, 2012). The importance of riparian forest and vegetation cover on the thermal structure of a stream cannot be overemphasized, and the high vegetation cover at the lower reach of Ori stream may have kept the stream's temperature within an optimal range for aquatic life.

Generally, the community structures of the three groups of organisms studied were a clear indication of poor biological water quality and habitat structure with ShannonWeiner diversity index (H') $<3.0$ and Margalef index (d) $<3.0$ (Türkmen and Kazanc1, 2010). The spatial trend in the species richness and abundance of the organisms also revealed the effects of environmental stress on the stream and its recovery pattern. The effects of anthropogenic activities seemed to be most pronounced at the upper reach where human and abattoir wastes were being disposed. The effects of these depositions were not only felt at the upper reach but also at the middle and lower reaches, as indicated by their poor physicochemical and biological water quality. The stream however appeared to have recovered from the stress at its lower reach before discharging into River Oba. This was most likely as a result of biodegradation of the organic wastes in the stream as it flowed down, from its upper reach.

\section{Conclusion}

The study has shown that Ori stream is poor in terms of physico-chemical and biological water quality as a result of anthropogenic interferences. The spatial distribution of the organisms suggests that the effects of organic deposition in the upper reach were greatly felt in the middle reach, and the stream seemed to have slightly recovered from the stress before discharging into River Oba. Findings in this study also revealed that plankton are not the best biological tool for assessing the integrity of running waters at a specific site, since they drift with water current from an upstream station. It is also noteworthy to state that continual deposition of organic wastes in the stream would further worsen its water quality. It is therefore expedient that deposition of domestic and abattoir wastes in the stream, particularly at the upper reach, be discontinued in order to restore the biological integrity of the system. It is also recommended that conservation studies of large tropical inland waters (e.g. lakes and rivers) be extended to their tributaries in order to conserve the ecological integrity of the former.

\section{REFERENCES}

Akindele EO. 2013. Downstream assessment of the zooplankton fauna and hydrology of Aiba stream, Iwo, Nigeria. Proceedings of the Nigerian Tropical Biology Association Conference, 47-53. 
Akindele EO, Adeniyi IF. 2013. Zooplankton composition and community structure in Lake Tiga, Kano, Nigeria. African Journal of Aquatic Science, 38(3): 279286.

Akindele EO, Liadi AA. 2014. Diversity and response of benthic macroinvertebrates to natural and induced environmental stresses in Aiba stream, Iwo, Southwest Nigeria. West African Journal of Pure and Applied Ecology, 22: 101-111.

Akindele EO, Olutona GO. 2014. Water Physico-chemistry and Zooplankton Fauna of Aiba Reservoir Headwater Streams, Iwo, Nigeria. Journal of Ecosystem, 2014: 11.

Akin-Oriola GA. 2003. Zooplankton association and environmental factors in Ogunpa and Ona rivers, Nigeria. Rev. Biol. Trop., 51(2): 391-398.

Alberto WD, Del Pilar DM, Valeria AM, Fabiana PS, Cecilia HA, De Los Angeles BM. 2001. Pattern recognition techniques for the evaluation of spatial and temporal variations in water quality. A case study of Suqu'́a River Basin (Cordoba- Argentina). Water Research, 35: 2881-2894.

Atobatele EO, Olutona GO. 2013. Spatioseasonal physico-chemistry of Aiba stream, Iwo, Nigeria. African Journal of Biotechnology, 12(14): 1630-1635.

Ayodele HA, Adeniyi IF. 2006. The zooplankton fauna of six impoundments on River Osun, Southwest, Nigeria. The Zoologist, 1(4): 49-67.

Bhat SA, Pandit AK. 2014. Surface Water Quality Assessment of Wular Lake, A Ramsar Site in Kashmir Himalaya, Using Discriminant Analysis and WQI. Journal of Ecosystems, 2014: 18.

Bhat SA, Meraj G, Yaseen S, Pandit AK. 2014. Statistical assessment of water quality parameters for pollution source identification in Sukhnag stream, an inflow stream of Lake Wular (Ramsar site), Kashmir Himalaya. Journal of Ecosystems, 2014: 18.
Bilby RE, Ward JW. 1991. Characteristics and functions of large woody woody debris in streams draining old growth, clear cut, and second-growth forests in Southwestern Washington. Can. J. Fish. Aquat. Sci., 48: 2499-2508.

Carr GM, Neary JP. 2006. Water Quality for Ecosystem and Human Health. United Nations Environment Programme Global Environment Monitoring System (GEMS)/ Water Programme.

Chapman D, Kimstach V. 2006. Selection of water quality variables. In Water Quality Assessments, Chapman D (ed). Chapman and Hall: London; 65-122.

Chinhanga JR. 2010. Impact of industrial effluent from an iron and steel company on the physico-chemical quality of Kwekwe River water in Zimbabwe. International Journal of Engineering, Science and Technology, 2(7): 29-40.

Freshwater Biological Association. 2011. Guide to British Freshwater Macroinvertebrates for Biotic Assessment. The Freshwater Biological Association: Ambleside, UK.

Fernando CH. 2002. A Guide to Tropical Freshwater Zooplankton; Identification, Ecology and Impact on Fisheries. Backhuys Publishers: Leiden.

Friedrich G, Chapman D, Beim A. 2006. The use of biological material. In Water Quality Assessments, Chapman D (ed). Chapman and Hall: London; 167-227.

Hambler C, Canney SM. 2013. Conservation $\left(2^{\text {nd }}\right.$ edn). Cambridge University Press: UK.

Higgins J, Duigan C. 2009. So much to do, so little time: identifying priorities for freshwater biodiversity conservation in the USA and Britain. In Assessing the Conservation Value of Freshwaters: An International Perspective, Boon PJ, Pringle CM (eds). Cambridge University Press: UK; 61-90.

Hussain QA, Pandit AK. 2012. Macroinvertebrates in streams: A review of some ecological factors. International 
Journal of Fisheries and Aquaculture, 4(7): 114-123.

Iliopoulou-Georgudaki J, Kantzaris V, Katharios P, Kaspiris P, Georgiadis T, Montesantou B. 2003. An application of different bioindicators for assessing water quality: a case study in the rivers Alfeios and Pineios (Peloponnisos, Greece). Ecol Indic., 2(4): 345-360.

Kettler TA, Doran JW, Gilbert TL. 2001. Simplified method for soil particle-size determination to accompany soil-quality analyses. Publications from USDA-ARS / UNL Faculty. Paper 305. http://digitalcommons.unl.edu/usdaarsfa cpub/305.

Millennium Ecosystem Assessment. 2005. Ecosystems and human well-being: current states and trends. In Findings of the Condition and Trends Working Group, Hassan R, Scholes R, Ash N (eds). Island Press: Washington, DC.

Molnar W. 2005. Praire and plot primary productivity. Laboratory Investigations for AP Environmental Science. http://lhsapes.weebly.com/uploads/3/2/3/ 9/3239894/primary_productivity_labprairie_pond.pdf.

Qadir A, Malik RN, Husain SZ. 2008. Spatiotemporal variations in water quality of Nullah Aik-tributary of the River Chenab, Pakistan. Environmental Monitoring and Assessment, 140: 43-59.

Simeonov V, Stratis JA, Samara C et al. 2003. Assessment of the surface water quality in Northern Greece. Water Research, 37: 4119-4124.

Singh KP, Malik A, Mohan D, Sinha S. 2004. Multivariate statistical techniques for the evaluation of spatial and temporal variations in water quality of Gomti River (India): a case study. Water Research, 38: 3980-3992.

Singh UB, Ahluwalia AS, Sharma C, Jindal R, Thakur RK. 2013. Planktonic indicators: A promising tool for monitoring water quality (early-warning signals). Eco. Env. \& Cons., 19(3): 793-800.

Türkmen G, Kazancı N. 2010. Applications of various diversity indices to benthic macroinvertebrate assemblages in streams of a natural park in Turkey. BALWOIS 2010-Ohrid, Republic of Macedonia - 25, 29 May 2010

Umar DM, Harding JS, Winterbourn MJ. 2013. Freshwater Invertebrates of the Mambilla Plateau, Nigeria. School of Biological Sciences, University of Canterbury: New Zealand.

United States Environmental Protection Agency. 2007. Re-cent Recommended Water Quality Criteria. http://www. epa.gov/waterscience/criteria/wqcriteria. html.

Voshell JR. 2002. A Guide to Common Freshwater Invertebrates of North America. The McDonald and Woodward Publishing Company: Granville, Ohio.

World Resources Institute in collaboration with the United Nations Environment Programme, the United Nations Development Programme, and the World Bank. 2000. World Resources 2000-2001: People and Ecosystems- the Fraying Web of Life. World Resources Institute: Washington, DC. 